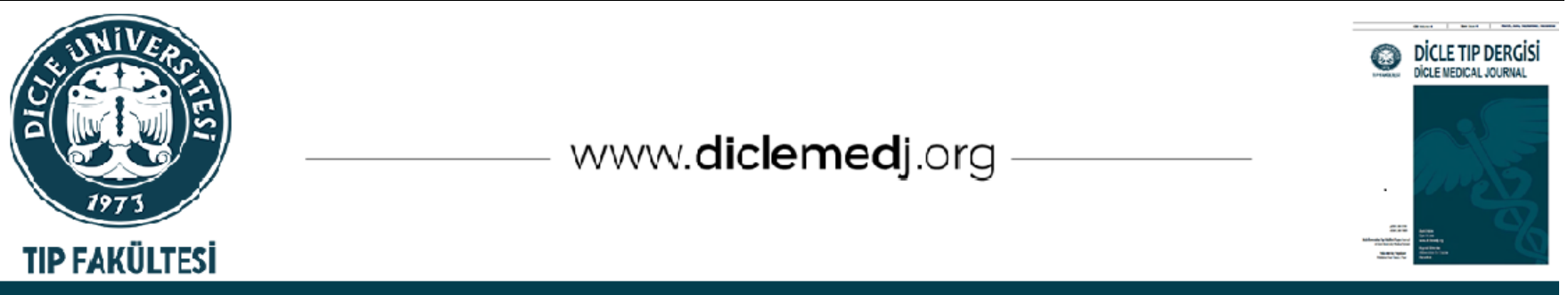

Original Article / Özgün Araştırma

\title{
Ventriculoperitoneal shunt infections in children; 10 years of experience in a single center
}

\author{
Kamil Yılmaz ${ }^{\text {D }} 1$ \\ 1 Department of Pediatrics, Dicle University Medical School, Diyarbakir, Turkey
}

Received: 30.09.2020; Revised: 27.10.2020; Accepted: 24.11.2020

\begin{abstract}
Objective: Shunt infections are a serious health problem seen in children. Our aim in this study is to investigate the clinical features, bacterial pathogens and antimicrobial treatments of pediatric patients with ventriculoperitoneal shunt infection.
\end{abstract}

Methods: This retrospective study included 108 pediatric patients with ventriculoperitoneal shunt infection who were followed up in the Pediatric Infection Clinic of Dicle University Medical Faculty between January 2009 and December 2019.

Results: The cases were $48.1 \%$ male and $51.9 \%$ female. Ventriculoperitoneal were placed in $70.4 \%$ of the cases when they were $0-1$ months old, and in $15.7 \%$ of the cases when they were $2-3$ months old. The most common cause of ventriculoperitoneal shunt implantation was congenital hydrocephalus (90.7\%), followed by central nervous system tumors (5.6\%) and central nervous system infections $(2.8 \%)$. The most common clinical signs and symptoms were fever (91.7\%), vomiting (87\%), convulsion (49.1\%), change of consciousness (50.9\%), meninx irritation finding (37.0\%), anterior fontanelle cuff (65.7\%), shunt leak (57.4\%) and abdominal symptoms (62\%). The most frequently isolated pathogens from cerebrospinal fluid cultures were Coagulase negative staphylococcus (36.1\%), Staphylococcus aureus (14.8\%), Klebsiella pneumoniae (13\%), Pseudomonas aeruginosa (6.5\%), Acinetobacter baumannii (16\%) and Escherichia coli (11.1\%). The most commonly used antibiotics in treatments were vancomycin (68.5\%), meropenem (67.5\%), ceftriaxone (45.3\%), colimycin (26.8\%), amikacin (25\%), linezolid (21.2\%) and cephotaxime $(9.2 \%)$. The mortality rate of the patients was $20.4 \%$.

Conclusions: Knowing the risk factors and taking early precautions in ventriculoperitoneal shunt infections can significantly reduce shunt infections, and better results can be obtained by determining the possible pathogens and starting empirical treatment accordingly.

Keywords: Ventriculoperitoneal shunt infections, children, risk factors, pathogens, treatment

DOI: 10.5798/dicletip.850282

Correspondence / Yazışma Adresi: Kamil Yılmaz, Dicle University School of Medicine, Department of Pediatric Infectious Diseases, Diyarbakir, Turkey, e-mail:drkamilyilmaz@gmail.com 


\section{Çocuklarda Ventriküloperitoneal Şant Enfeksiyonları; Bir Merkezde 10 Yıllık Deneyim} Öz

Amaç: Şant enfeksiyonları çocuklarda görülen ciddi sağlık problemlerinden biridir. Bu çalışmada amacımız Ventriküloperitoneal şant (VP) enfeksiyonu olan pediatrik hastaların klinik özellikleri, bakteriyel patojenleri ve verilen antimikrobiyal tedavilerin araştırılmasıdır.

Yöntemler: Bu retrospektif çalışmaya, Dicle Üniversitesi Tıp Fakültesi, pediatrik infeksiyon kliniğinde Ocak 2009Aralık 2019 VP şant enfeksiyonu tanısıyla takip edilen 108 çocuk hasta alındı.

Bulgular: Çalışmaya dahil edilen olgular \%48,1'i erkek ve \%51,9'u kız olmak üzere toplam 108 hastadan oluştu. Olguların \%70,4'üne 0-1 aylık iken, \%15,7'sine 2-3 aylık iken Ventriküloperitoneal şant takıldı. Olgularda en sık Ventriküloperitoneal șant takılma nedeni en sık Konjenital hidrosefali $(\% 90,7)$, Santral sinir sistemi tümörleri $(\% 5,6)$ ve Enfeksiyon $(\% 2,8)$ idi. Olgularda en slk görülen klinik belirti ve bulgular Ateş (\%91,7), Kusma (\%87), Konvülziyon $(\% 49,1)$, Bilinç değişikliği $(\% 50,9)$, Meninks irritasyon bulgusu $(\% 37,0)$, Ön fontanel bombeliği $(\% 65,7)$, Şant sızıntısı $(\% 57,4)$ ve Abdominal semptomlar (\%62) idi. Beyin omurilik sıvısı kültürlerinden en sık Koagülaz negatif stafilokok $(\% 36,1)$, Staphylococcus aureus (\%14,8), Klebsiella pneumoniae (\%13), Pseudomonas aeruginosa (\%6,5), Acinetobacter baumannii $(\% 16,7)$ ve Escherichia coli $(\% 11,1)$ İzole edildi. Tedavide en sık kullanılan antibiyotikler vankomisin $(\% 68,5)$, meropenem $(\% 67,5)$, seftriakson $(\% 45,3)$, Kolimisin $(\% 26,8)$, amikasin $(\% 25)$, linezolid $(\% 21,2)$, sefotaksim $(\% 9,2)$ idi. Olgularda mortalite oranı \%20,4 idi.

Sonuç: Sonuç olarak, ventriküloperitoneal şant enfeksiyonlarında risk faktörlerinin bilinmesi ve erken önlem alınması ile şant enfeksiyonları önemli ölçüde azaltabilir ayrıca olası patojenlerin belirlenip onlara göre tedavi başlanması ile daha iyi sonuçlar alınabilir.

Anahtar kelimeler: ventriküloperitoneal şant enfeksiyonları, çocuk, risk faktörleri, patojenler, tedavi

\section{INTRODUCTION}

Hydrocephalus, for which ventriculoperitoneal shunt (VP) is usually used as a basic therapy in treatment, is a serious health problem still common in children all over the world. In patients with VP shunt insertion, the most common problems are shunt infections and shunt failure ${ }^{1,2}$. Despite all the technological developments, shunt infections continue to be common $^{2}$. The frequency of development of shunt infections may vary according to the presence of many risk factors such as young age, the cause of hydrocephalus (meningomyelocele, intracranial hemorrhage), the history of recurrent shunt infections, shunt attachment technique, the type of shunt inserted, the skill of the surgeon, the duration of the shunt and compliance with hygiene rules ${ }^{3,4}$.

Many clinical signs and symptoms such as headache, high fever, vomiting, meningeal irritation findings, toxic appearance, sleepiness, decreased sucking and eating, convulsion, anterior fontanelle tension and local infection symptoms at the catheter site can be seen in children with VP shunt infection for various reasons such as the age group of the patient, the development of meningitis, increased intracranial pressure and local infection at the catheter tip ${ }^{3}$.

In many previous studies, coagulase negative staphylococci, which are usually colonized bacteria on the skin, have been reported as the cause of most ventriculoperitoneal shunt infections, but nowadays, the frequency of gram negative bacterial infections has started to increase due to many factors ${ }^{5,6}$. In VP infections, which can cause high mortality and morbidity in affected children, early diagnosis and correct empirical antibiotic treatment are very important for the early recovery and prevention of complications ${ }^{3-7}$.

In this study, the clinical features, bacterial pathogens and antimicrobial treatments of 108 pediatric patients with VP shunt infection 
followed up for 10 years in a single center were investigated to be able to better guide clinical practices in the treatment of VP shunt infections in children.

\section{METHODS}

This retrospective study included 108 pediatric patients aged 0-15 years, who were followed up in the pediatric infection clinic of Dicle University Medical Faculty between January 2009 and December 2019 with the diagnosis of VP shunt infection. Only patients with clinical and laboratory findings suggesting VP shunt infection and also pathogen reproduction in the cerebrospinal fluid culture were included in the study. Patients were excluded from the study if they had severe systemic complaints not related to shunt infection even if there was growth in the cerebrospinal fluid culture, if they were considered to have contamination but clinical and laboratory findings did not suggest VP shunt infection, and those with missing data. A record was made for all cases of age (month), gender, shunt insertion age (days), shunt insertion cause [congenital hydrocephalus, central nervous system (CNS) tumor, intraventricular hemorrhage and CNS infections (meningitis, encephalitis)], clinical signs and symptoms (vomiting, fever, convulsion, altered consciousness), meninx irritation sign, anterior fontanelle cuff, shunt leak, abdominal symptoms, duration of hospitalization (days), data of pathogenic pathogens in cerebrospinal fluid culture, and prognosis. In all patients, infected shunts were removed, external drainage was applied, and appropriate antibiotic therapy was initiated. Patients who recovered completely in clinical and laboratory findings after antibiotic treatment were discharged after reinserting VP shunts.

\section{Statistical Analysis}

Data obtained in the study were analyzed statistically using SPSS vn. 20 software (Statistical Package for the Social Sciences, Chicago, IL, USA). Descriptive statistics analyses were stated as frequency, percentage, mean \pm standard deviation (SD), median, minimum and maximum values. A value of $\mathrm{p}<0.05$ was accepted as statistically significant.

\section{RESULTS}

The 108 cases included in this study comprised 52 (48.1\%) males and 56(51.9\%) females with a mean age of $28.3 \pm 43.6$ weeks (range, 1-196 months). The mean length of stay in hospital was $46.6 \pm 44.7$ days. VP shunt was placed within 1 month after birth to $70.4 \%$ of cases (Table 1). The most common reason for VP shunt insertion was congenital hydrocephalus at the rate of $90.7 \%$. The most common complaints of the patients on admission were vomiting and fever (Table 1 ).

Table I: Demographic and clinical characteristics of the cases.

\begin{tabular}{|c|c|c|c|}
\hline & & 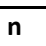 & $\%$ \\
\hline \multicolumn{4}{|l|}{ Gender } \\
\hline & Male & 52 & 48.1 \\
\hline & Female & 56 & 51.9 \\
\hline \multicolumn{4}{|c|}{ VP shunt insertion age } \\
\hline & $0-1$ months & 76 & 70.4 \\
\hline & 2-3 months & 17 & 15.7 \\
\hline & 4-6 months & 4 & 3.7 \\
\hline & 7-12 months & 5 & 4.6 \\
\hline & 13 months and over & 6 & 5.6 \\
\hline \multicolumn{4}{|c|}{ VP shunt insertion reason } \\
\hline & $\begin{array}{l}\text { Congenital } \\
\text { hydrocephalus }\end{array}$ & 98 & 90.7 \\
\hline & CNS tumors & 6 & 5.6 \\
\hline & CNS infections & 3 & 2.8 \\
\hline & $\begin{array}{l}\text { Intraventricular } \\
\text { bleedings }\end{array}$ & 1 & 0.9 \\
\hline \multicolumn{4}{|c|}{ Clinical signs and symptoms } \\
\hline & Fever & 99 & 91.7 \\
\hline & Vomiting & 94 & 87.0 \\
\hline & $\begin{array}{l}\text { Anterior fontanelle } \\
\text { bombing }\end{array}$ & 71 & 65.7 \\
\hline & Abdominal symptoms & 67 & 62 \\
\hline & Shunt leak & 62 & 57.4 \\
\hline & $\begin{array}{l}\text { Change of } \\
\text { consciousness }\end{array}$ & 55 & 50.9 \\
\hline & Convulsion & 53 & 49.1 \\
\hline & Meninx irritation signs & 40 & 37 \\
\hline \multicolumn{4}{|l|}{ Outcome } \\
\hline & Survival & 86 & 79.6 \\
\hline & Non-survival & 22 & 20.4 \\
\hline
\end{tabular}


The most frequently isolated gram positive pathogens from the cerebrospinal fluid culture were Coagulase negative staphylococci (S. epidermidis etc.) and Staphylococcus aureus, while the most frequently isolated gram negative pathogens were Acinetobacter baumannii and Klebsiella pneumoniae (Table 2).

Table II: Pathogens isolated from cerebrospinal fluid culture.

\begin{tabular}{|lcc|}
\hline Pathogens & n & \% \\
\hline Coagulase negative staphylococcus ( S. & 39 & 36.1 \\
Epidermidis etc.) & & \\
Acinetobacter baumannii & 18 & 16.7 \\
Klebsiella pneumoniae & 14 & 13.0 \\
Escherichia coli & 12 & 11.1 \\
Methicillin- sensitive & Staphylococcus & \\
aureus & 8 & 7.4 \\
Methicillin- resistant & Staphylococcus & \\
aureus & 8 & 7.4 \\
Pseudomonas aeruginosa & 7 & 6.5 \\
Candida albicans & 2 & 1.9 \\
Total & 108 & 100.0 \\
\hline
\end{tabular}

The most common types of antibiotherapy given to patients for treatment were vancomycin $68.5 \%$ (74), meropenem $67.5 \% \quad$ (73), ceftriaxone $45.3 \%$ (49), Colimycin $26.8 \%$ (29), amikacin 25\% (27) ,linezolid 21.2\% (23), cefotaxime $9.2 \%$ (10), Teicoplanin 6.4\% (7) and Sulperazon 3.7\% (4). Antifungal treatment for prophylactic or therapeutic purposes was given to $38(35.2 \%)$ patients. In 67 (62\%) cases, antibiotic revision was made due to insufficient response to the first initiated antibiotherapy.

\section{DISCUSSION}

Although VP shunt is used to treat hydrocephalus caused by increased cerebrospinal fluid, in pediatric patients it can lead to $3-20 \%$ shunt infections, which constitute an important threat for children ${ }^{8}$. Previous studies have reported that this condition may be due to the weak humoral and cellular immune systems, the immature skin barrier and the features of the skin bacterial flora in this age group ${ }^{8}$. In addition, there are risk factors related to the surgical procedure, including postoperative cerebrospinal fluid leaks, the frequency of manual contact between the neurosurgeon and the shunt system, duration of the surgical procedure, surgeon's experience or use of single gloves rather than the intraoperative double glove strategy ${ }^{9}$. In this study, most of the children with shunt infection had shunts when they were under 1 month old and the majority of these patients had congenital hydrocephalus. Therefore, it is very important to follow the patients more frequently, especially in the very young age group and congenital hydrocephalus cases ${ }^{10}$.

Children with shunt infections may have a wide range of clinical signs and symptoms due to age, increased intracranial pressure associated with shunt infection, local signs of infection and gastrointestinal manifestations. Especially in patients presenting with shunt dysfunction symptoms, infection should always be suspected, as shunt infection is a serious complication with the potential for morbidity and mortality ${ }^{11,12}$. Patients with shunt dysfunction often have symptoms such as fever and signs of infection, but more rarely, patients with shunt failure for any reason may develop nausea, vomiting, headache, altered consciousness, weakness, drowsiness, irritability and redness, but fever is still a major symptom in patients with shunt infection ${ }^{11-14}$. In a previous study, the most common symptoms of shunt infections were fever (91.4\%), local signs of infection (34.3\%), irritability (20\%), abdominal pain $(17.1 \%)$, convulsion (17.1\%) and neurological change (17.1\%), and in another study, fever (48.3\%), general condition disorder (24.1\%) headache (17.2\%), nausea and vomiting $(6.9 \%)$, convulsion $(6.9 \%)$ and shunt dysfunction (6.9\%) were the most 
common symptoms of shunt infections ${ }^{8,10}$. In the current study, the most common symptoms were fever $(91.7 \%)$, vomiting $(87.0 \%)$, anterior fontanelle cuff (65.7\%), shunt leak (57.4\%), abdominal symptoms (62\%), convulsion (49.1\%), altered consciousness (50.9\%) and meninx irritation findings (37.0\%). In the light of these results, it can be understood that fever and vomiting are very important symptoms, especially in young children.

Although the frequency of pathogens causing VP shunt infections varies depending on many factors, the most frequently isolated pathogens have been reported as Staph epidermidis, Staph aureus and gram negative pathogens in many previous studies, $82,15-17$. Gram-positive bacteria, which are colonized opportunistic pathogens in the skin of patients, appear relatively early after shunt placement, while gram-negative bacteria cause illness, especially in patients hospitalized for a long time $\mathrm{e}^{8,12,16}$. The frequency of gram-negative bacteria has also started to increase due to the technological possibilities and prolonged hospitalization ${ }^{8-10}$. It has been reported that gram negative bacilli are responsible for $7-27.5 \%$ of all VP shunt infections ${ }^{3,8,10}$. In a multicenter study conducted in Turkey, the most isolated pathogens from VP shunt infections were reported to be coagulase negative staphylococci (42.5\%), Pseudomonas aeruginosa (14.9\%), K. pneumoniae (10.1\%) and $S$ aureus (10.1\%) (14). In a recent study, 82.6\% S. epidermidis, 8.6\% Enterococcus, $4.3 \%$ E. coli and $4.3 \%$ Pseudomonas aeruginosa were found most frequently in patients with VP shunt infection ${ }^{18}$. In the current study, the most frequently isolated pathogens were $\mathrm{S}$. epidermidis (36.1\%), Staphylococcus aureus (14.8\%), Klebsiella pneumoniae (13\%), Pseudomonas aeruginosa (6.5\%), Acinetobacter baumannii (16.7\%). Escherichia coli $(11.1 \%)$ and Candida albicans (1.9\%). As can be understood from these results, gram negative hospital infections have started to increase gradually, so this should be taken into consideration when starting empirical antibiotic treatment.

VP shunt infections are difficult to treat, due to both increasing antibiotic resistance and anatomic difficulties associated with the introduction of antibiotics into the brain ${ }^{19}$. A pediatric population study reported that in addition to antibiotic treatment, removing the VP shunt temporarily is the most effective approach to eliminate shunt infection ${ }^{6}$. In the VP shunt infections treatment guideline of The Infectious Diseases Society of America it is recommended that glycopeptide should be administered as empirical antibiotic treatment and, if necessary, in combination with ceftazidime, cefepime or meropenem ${ }^{20}$. In a recent study, it was reported that the treatment response of cerebrospinal fluid shunt infections caused by Gram-negative bacteria is significantly better than infections caused by Gram-positive bacteria ${ }^{6}$. In this study, after VP shunt was removed in all patients, $68.5 \%$ vancomycin, $67.5 \%$ meropenem, $45.3 \%$ ceftriaxone, 26.8\% Colimycin, 25\% amikacin, $21.2 \%$ linezolid and $35.2 \%$ prophylactic antifungal therapy were given according to the clinical condition of the patients. In addition, $62 \%$ of patients underwent antibiotic revision. In the light of these results, it can be understood that starting empirical antibiotic treatment for gram-positive bacteria as well as gram-negative bacteria is very important in the treatment after the VP shunt is removed.

In conclusion, the treatment of shunt infections remains very difficult and costly. Therefore,

taking early precautions, can significantly reduce the infection rates, and better success

can be achieved by determining possible $p$ athogens before empirical treatment and starting treatment accordingly.

The most important limitations of this study were the retrospective design and that there 
was no control group to evaluate the risk factors of VP shunt infections.

Acknowledgements:I appreciate the University Medical School of Dicle for providing access to their patient data.

Ethics Committee Approval: The study was conducted based on the rules of Declaration of Helsinki and approved by the Institutional Ethics Committee of Dicle University, Faculty of Medicine (Document number: 16.07.2020-247).

Declaration of Conflicting Interests: The authors declare that they have no conflict of interest.

Financial Disclosure: No financial support was received.

\section{REFERENCES}

1. Ragel BT, Browd SR, Schmidt RH. Surgical shunt infection: significant reduction when using intraventricular and systemic antibiotic agents. J Neurosurg 2006; 105: 242-7.

2. Prusseit J, Simon M, von der Brelie C, et al. Epidemiology, prevention and management of ventriculoperitoneal shunt infections in children. Pediatr Neurosurg 2009; 45: 325-36.

3. Tunkel AR, Hasbun R, Bihimraj A, et al. Infectious diseases society of america's clinical practice guidlines for healthcare- associated ventriculitis and menengitis. Clin Infect Dis 2017; 64: 34-65.

4. Simon TD, Butler J, Whitlock KB, et al; Hydrocephalus clinical research network. Risk factors for first cerobrospinal fluid shunt infection: findings from a multi-center prospective cohort study. J Pediatr 2014; 164: 1462-8.

5. McGirt MJ, Zaas A, Fuchs HE, et al. Risk factors for pediatric ventriculoperitoneal shunt infection and predictors of infectious pathogens. Clin Infect Dis 2003; 36: 858-62.

6. Mostafavi SN, Khedmati M, Kelishadi R. A Seven-year study on the effects of intravenous antibiotic therapy on infection of ventriculoperitoneal shunts in children. Pediatr Infect Dis J 2020: Mar 30.

7. Attenello FJ, Garces-Ambrossi GL, Zaidi HA, Sciubba DM, Jallo GI. Hospital costs associated with shunt infections in patients receiving antibiotic-impregnated shunt catheters versus standard shunt catheters. Neurosurgery 2010; 66: 284-9.
8. Lee JK, Seok JY, Lee JH, et al. Incidence and risk factors of ventriculoperitoneal shunt infections in children: A study of 333 consecutive shunts in 6 years. J Korean Med Sci 2012; 27: 1563-8.

9. Kulkarni AV, Drake JM, Lamberti-Pasculli M. Cerebrospinal fluid shunt infection: a prospective study of risk factors. J Neurosurg 2001; 94: 195-201.

10. Gokce Z, Aydin G, Aydemir D, et al. Evaluation of ventriculoperitoneal shunt infections in children. J Pediatr Inf 2018; 12: 147-52.

11. K. Wang, W. Chang, T. Shih, et al. Infection of cerebrospinal fluid shunts: causative pathogens, clinical features, and outcomes. Jpn J Infect Dis 2004; 57: 44-8.

12. Paff $M$, Abrams DA, Muhonen $M$, Loudon W. Ventriculoperitoneal shunt complications: A review. Interdisciplinary Neurosurg 2018; 13: 66-70

13. Tunkel AR, Hasbun R, Bhimraj A, et al. Infectious diseases society of america's clinical practice guidelines for healthcare-associated ventriculitis and meningitis. Clin Infect Dis 2017; 6: 34-65.

14. Yakut N, Soysal A, Kadayifci EK, et al. VP shunt infections and re-infections in children: a multicentre retrospective study. Br J Neurosurg 2018; 32: 196-200.

15. Zervos T, Walters BC. Diagnosis of ventricular shunt infection in children: a systematic review. World Neurosurg 2019; 129: 34-44.

16. McClinton D, Carraccio C, Englander R. Predictors of ventriculoperitoneal shunt pathology. Pediatr Infect Dis J 2001; 20: 593-7.

17. Erps A, Roth J, Constantini S, Lerner-Geva L, Grisaru-Soen G. Risk factors and epidemiology of pediatric ventriculoperitoneal shunt infection. Pediatr Int 2018; 60: 1056-61.

18. Gundeslioglu 00, Haytoglu Z, Ozsoy KM, Alabaz D, Kocabas E. Ventriculoperitoneal shunt infections in children: Demographical, clinical findings and evaluation of thrombocyte parameters. J Pediatr Inf 2018; 12: 63-9.

19. Gutierrez-Murgas Y, Snowden JN. Ventricular shunt infections: Immunopathogenesis and clinical management. J Neuroimmunol 2014; 276: 1-8.

20. Anderson EJ, Yogev R. A rational approach to the management of ventricular shunt infections. Pediatr Infect Dis J 2005; 24: 557-8. 